\title{
Processing and the nutritional contents of canned and fresh pigeon peas (Cajanus cajan (L.))'
}

\author{
Orlando Parsi-Ros, Edelmiro J. Rodríguez-Sosa, José Cruz-Cay and \\ Magaly E. Cintrón-Muñoz
}

\begin{abstract}
Two portions of pigeon peas, Cajanus cajan (L.), were processed with and without the application of steam blanching, blanching with water immersion and exhausting to determine the nutritional contents of the pigeon peas after each treatment.

The results obtained from the comparison of the nutritional content of the peas imply the possibility of the loss or retention of some of the nutrients. Steam blanching could be the cause of the nutritional loss of $\mathbf{N a}$, $K$, and $\mathrm{Fe}$, and blanching with water immersion could be the cause of the loss of $\mathrm{K}, \mathrm{Ca}$ and $\mathrm{Mg}$ and could be a determinant factor for the retention of Fe. Exhausting could be the cause of the loss of $\mathrm{K}, \mathrm{Ca}, \mathrm{Mg}, \mathrm{Fe}$ and vitamin $\mathbf{B}_{\mathbf{2}}$.
\end{abstract}

\section{INTRODUCTION}

Since the middle of this century, Puerto Rico has evolved from a society highly dependent on agriculture to one that is highly urban and industrial. Hence, processing of foods is now a vital part of the Island's way of life.

Processing affects appearance, flavor, texture and nutritional value of foods. Some of the changes which occur during processing are desirable; however, undesirable changes also occur. One such change of great concern is the loss of nutrients $(4,9,15,17,18)$.

Most of the highly nutritious foods, including many vegetables are highly perishable. Without adequate processing, the quality and nutritive value of these products are lost. Processing may lead to an inevitable loss in certain nutrients. Today, it is well known that nutrients are sensitive to heat, oxygen, light, trace metals, $\mathrm{pH}$ or a combination of these factors $(3,6,14,16,19,23)$. Foods, when processed, are submitted to one or more of these factors. Although food processing in general could

${ }^{1}$ Manuseript submitted to Editorial Board February 14, 1986.

${ }^{2}$ Research Assistant, Food Technologist, Associate Food Technologist, and Research Assistant, Food Technology Laboratory, Agricultural Experiment Station, Mayagüez Campus, University of Puerto Rico, Río Piedras, P. R. The authors thank E. Fontanet de Gotay, Associate Statistician, for her cooperation with the analysis of variance and S. Villafañe de Colom, Former Associate Chemist, for her cooperation with the laboratory analyses. 
affect all nutrients, the most widely studied nutrients are the vitamins $(5,10,13,20)$.

In the past, nutrient composition of food products was largely disregarded by many processors. Since the publication in 1973 of the Nutrition Labeling Regulations by the Food and Drug Administration, and more recently with the enactment of the Food Labeling Act, concern for the nutritional content of foods greatly increased among food processors and the general public. This processor awareness, prompted by the federal government and by the consumer's interest, emphasizes the importance of obtaining information about nutrient retention or losses during processing and storage so that optimum quality can be obtained in the processed products.

In Puerto Rico, there are some 350 food and related manufacturing plants processing a variety of foodstuffs (1). More than two-thirds of these plants are of local origin; the others are subsidiaries of U.S. firms and of foreign based companies. Although some of these plants are large, with enough resources, the great majority of them are medium size and small family type, with scarce resources to provide for any research or analytical work. Thus, nutrient data on the different processing steps and storage are lacking.

Puerto Rico harvested 100,000 hundredweight of pigeon peas in 1982$83,36,000$ hundredweight of which was processed for local use. In $1983-$ 84 , there was an increase in the harvest and in the processing of 105,000 hundredweight and 42,000 hundredweight, respectively $(7,8)$.

Much data on nutrient composition of foods available in the literature were obtained many years ago. Since that time, there have been many changes in the industrial processes and sometimes in the raw materials. These could have resulted in an altered nutrient content. Furthermore, it is well known that raw foods may vary widely in their composition because of genetic variations, soils and climatic conditions, and maturity at harvest (12).

With few exceptions (2), no information is readily available on most of the foods processed in Puerto Rico. Data are, therefore, urgently needed on the nutrient content of raw as well as processed foods produced in Puerto Rico.

Adequate nutritional data are especially needed on many of the products such as pigeon peas, beans, green bananas, sweet potatoes, snack items, juices, nectar's and meats processed in Puerto Rico. Information on the destruction of nutritional value during processing and storage must be obtained to minimize nutrient losses. As long as nutrition remains a problem prevalent in large areas of the world, the nutrient retention in processed foodstuffs cannot be neglected. 
This research was done to obtain nutritional data on pigeon peas, Cajanus cajan (L.), harvested in Puerto Rico and processed with different treatments such as steam blanching, blanching with water immersion and exhausting.

\section{MATERIALS AND METHODS}

One hundred fifteen pounds of pigeon peas, harvested in southern Puerto Rico, was processed at the Food Technology Laboratory in Río Piedras, Puerto Rico.

The objectives were: 1) The processing of two portions of pigeon peas with and without the application of different treatments and the determination of their nutritional contents after each treatment; 2) the determination of the nutritional contents of the eanned pigeon peas during a storage period of 0 - to 6 -months.

The treatments were blanching with steam $\left(90 \mathrm{sec}, 2^{\circ} \mathrm{F}\right)$ of pigeon pea pods; blanching the peas with water immersion $\left(5 \mathrm{~min}, 185^{\circ} \mathrm{F}\right.$ ) and exhausting the peas (10 min., $\left.212^{\circ} \mathrm{F}\right)$ in No. 303 cans without the lids with a brine solution of $2 \% \mathrm{NaCl}$ as shown in Figure 1.

The pigeon pea pods were divided into two portions, $A$ and $B, 56 \mathrm{lb}$. each. Portion $A$ was passed directly to the huller machine without the application of steam blanching, and portion B was treated with steam blanching before dehulling.

Samples were obtained after each procedure and placed in plastic bags that were heated, sealed, and transferred to a freezer. All the samples of pigeon peas obtained during the different treatments of the process were handled the same way.

The pigeon peas from each portion were transferred to a picking table, where undesirable particles and dry or rotten peas were discarded. We counted green and ripe pigeon peas to determine the percentage of ripe peas of each portion as shown in the following tabulation.

$\begin{array}{lcc} & \text { Portion A } & \text { Portion B } \\ \text { Green } & 740 & 649 \\ \text { Ripe } & 113 & 102 \\ \text { Total } & 853 & 751 \\ \text { Ripe \% } & 13.2 & 13.6\end{array}$

We blanched with water immersion and then water cooled the chosen peas of portions $A$ and $B$, and put the samples in plastic bags.

Ten-0z. portions were transferred to No. 303 enameled cans with a boiling $2 \%$ brine solution. The brine was prepared with tap water and commercial salt without iodine.

The cans from each portion were divided into two groups. One group of each portion was passed through an exhausting tunnel $(24,25)$, sealed 
Portion A: Treatments

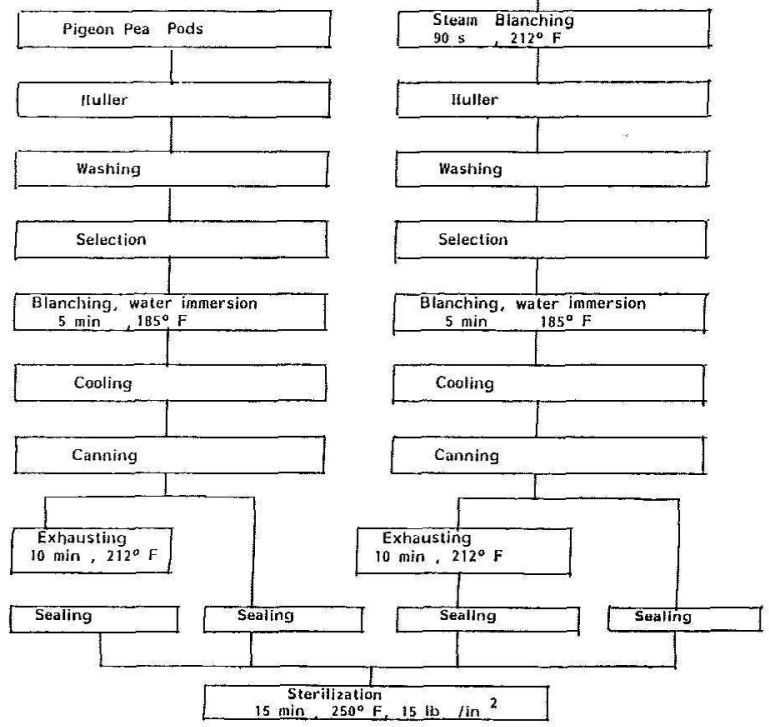

Fig. 1.-The different treatments applied to the two portions of pigeon peas.

and labeled. The other group from each portion was passed without exhausting to the ean sealing machine and labeled.

The last treatment of the process was completed with the commercial sterilization in an autoclave $\left(15 \mathrm{~min} ., 250^{\circ} \mathrm{F}\right.$ and $\left.15 \mathrm{lb} / \mathrm{in}^{2}\right)$ followed by water cooling.

To determine the effect of the exhausting treatment the labeled cans were opened, the water was discarded and the peas were transferred to plastic bags.

All the samples were analyzed in duplicate to determine their protein, $\mathrm{N}, \mathrm{K}, \mathrm{Ca}, \mathrm{Na}, \mathrm{P}, \mathrm{Mg}, \mathrm{Mn}, \mathrm{Fe}$, vitamin $\mathrm{B}_{2}$ contents, total fats and ash. 
The nitrogen content was determined according to the micro-Kjeldahl method A.O.A.C. (22). The protein content was obtained by multiplying the nitrogen content by 6.25 . The $\mathrm{Mg}, \mathrm{K}, \mathrm{Na}$ and $\mathrm{Ca}$ content was determined by flame photometry with a Perkin Elmer, UV-Vis Spectrophotometer ${ }^{3}$.

The $\mathrm{P}$ content was determined according to the method of Fiske and Subarrow (20) with a Technicon Auto Analyzer (11).

The $\mathrm{Mn}$ and $\mathrm{Fe}$ content was determined according to the method of Perch Seywell and Cunningham with a Perkin Elmer, UV-Vis Spectrophotometer.

The vitamin $B_{2}$ content was determined with the fluorometric methods of Vitamin Assays (21).

The total fat and ash contents were determined according to A.O.A.C. (22).

The results of the analyses of the nutritional contents were statistically analyzed for the possibility of a significant difference among the nutritional contents of the pigeon peas obtained from the different processing treatments.

\section{RESULTS}

Table 1 summarizes the nutritional contents of pigeon peas before and after steam blanching the pods.

The analyses of variance indicate that the nutritional contents of $K$, $\mathrm{Na}$ and $\mathrm{Fe}$ have a significant difference $(\mathrm{P}=0.05)$ between application and nonapplication of the treatments.

The results imply that the treatment contributes to the loss of $\mathrm{K}, \mathrm{Na}$ and $\mathrm{Fe}$ and does not contribute significantly to the loss or retention of the other nutrients.

TABLE 1.-The nutritional contents of pigeon peas processed with treatments $A$ and $B$

\begin{tabular}{cccccccccccc}
\hline \multirow{2}{*}{ Treatment } & \multicolumn{10}{c}{ Contents } \\
\cline { 2 - 12 } & Protein & $\mathrm{P}$ & $\mathrm{K}$ & $\mathrm{Na}$ & $\mathrm{Ca}$ & $\mathrm{Mg}$ & $\mathrm{Mn}$ & $\mathrm{Fe}$ & Ash & Fats & Vit, $\mathrm{B}_{2}$ \\
\hline & $\%$ & $\%$ & $\%$ & $\%$ & $\%$ & $\%$ & $p / \%$ & $p^{\prime \prime m}$ & $\%$ & $\%$ & $\mu g^{\prime} g$ \\
$\mathrm{~A}^{1}$ & 19.99 & 0.39 & 1.95 & 0.02 & 0.11 & 0.22 & 10.00 & 97.50 & 4.96 & 1.79 & 1.53 \\
$\mathrm{~B}^{2}$ & 19.68 & 0.39 & 1.85 & 0.03 & 0.10 & 0.21 & 6.50 & 57.00 & 4.31 & 2.11 & 1.77 \\
\hline
\end{tabular}

${ }^{1}$ Processed without steam blanching.

$\approx$ Processed with steam blanching.

3 Trade names in this publication are used only to provide specific information. Mention of a trade name does not constitute a warranty of equipment or materials by the Agricultural Experiment Station of the University of Puerto Rico, nor is this mention a statement of preference over other equipment or materials. 
Table 2 summarizes the nutritional contents of the pigeon peas processed and not processed with steam blanching of the pods after blanching with water immersion.

According to the results of the analyses of variance it was determined that between the two treatments the contents of $\mathrm{K}, \mathrm{Ca}, \mathrm{Mg}$ and $\mathrm{Fe}$ have a significant difference $(\mathrm{P}=0.05)$.

These results imply that blanching of the pods contributes to the nutritional loss of $\mathrm{K}, \mathrm{Ca}$ and $\mathrm{Mg}$ and to the retention of $\mathrm{Fe}$.

Table 3 summarizes the nutritional contents of pigeon peas before and after exhausting of the canned pigeon peas in the brine solution.

From the analyses of variance, it was inferred that the contents of $\mathrm{K}, \mathrm{Na}, \mathrm{Ca}, \mathrm{Mg}, \mathrm{Fe}$, ash and vitamin $\mathrm{B}_{2}$ have a significant difference of $5 \%$ among the respective treatments: 1) $1-3,4,2-3,4$; 2) 1-2, 2-3, 4; 3) $2-3,4$; 4) $1-2,2-4$; 5) $1-2,3,2-4,3-4$; 6) $1-2,3,2-3$, 4; and 7) $1-2,3$, $4,2-3,4$.

The results imply that exhausting contributes to the nutritional loss of $\mathrm{K}, \mathrm{Ca}, \mathrm{Mg}, \mathrm{Fe}$ and vitamin $\mathrm{B}_{2}$, and that processing without exhausting contributes to the retention of $\mathrm{Mg}, \mathrm{Fe}$ and vitamin $\mathrm{B}_{2}$.

TABLE 2.-The nutritional contents of pigeon peas processed with treatments $A$ and $B$

\begin{tabular}{cccccccccccc}
\hline \multirow{2}{*}{ Treatment } & \multicolumn{10}{c}{ Contents } \\
\cline { 2 - 11 } & Protein & $\mathrm{P}$ & $\mathrm{K}$ & $\mathrm{Na}$ & $\mathrm{Ca}$ & $\mathrm{Mg}$ & $\mathrm{Mn}$ & Fe & Ash & Fats & Vit. $\mathrm{B}_{2}$ \\
\hline & $\%$ & $\%$ & $\%$ & $\%$ & $\%$ & $\%$ & $p i m$ & $p / m$ & $\%$ & $\%$ & $\mu g i g$ \\
$\mathrm{~A}^{*}$ & 19.87 & 0.35 & $\mathbf{1 . 4 6}$ & 0.04 & 0.14 & 0.21 & 7.50 & 64.50 & 3.82 & 2.29 & 1.17 \\
$\mathrm{~B}^{2}$ & 19.18 & 0.35 & 1.28 & 0.05 & 0.12 & 0.14 & 8.00 & 72.50 & 3.20 & 2.32 & 1.76 \\
\hline
\end{tabular}

1 Treatment of blanching with water immersion and without steam blanching.

2 Treatment of blanching with water immersion and with steam blanching.

TABLE 3.-The mutritional contents of pigeon peas processed with treatnents $I, I I, I I I$ and $I V$

\begin{tabular}{lccccccccccc}
\hline \multirow{2}{*}{ Treatment } & \multicolumn{10}{c}{ Contents } \\
\cline { 2 - 12 } & Protein & $\mathrm{P}$ & $\mathrm{K}$ & $\mathrm{Na}$ & $\mathrm{Ca}$ & $\mathrm{Mg}$ & Mn & Fe & Ash & Fats & Vit. $\mathrm{B}_{2}$ \\
\hline & $\%$ & $\%$ & $\%$ & $\%$ & $\%$ & $\%$ & $p / m$ & $p / m$ & $\%$ & $\%$ & $\mu / g$ \\
$\mathrm{I}{ }^{1}$ & 19.24 & 0.32 & 1.32 & 1.91 & 0.15 & 0.26 & 12.50 & 66.50 & 7.65 & 2.21 & 0.68 \\
II $^{2}$ & 18.87 & 0.31 & 1.27 & 1.83 & 0.14 & 0.22 & 10.00 & 65.50 & 7.20 & 2.32 & 0.66 \\
III $^{3}$ & 18.75 & 0.32 & 1.16 & 1.92 & 0.13 & 0.29 & 10.50 & 65.50 & 7.14 & 2.42 & 0.80 \\
IV $^{4}$ & 18.68 & 0.33 & 1.11 & 1.66 & 0.12 & 0.26 & 10.00 & 63.50 & 6.44 & 2.10 & 0.65 \\
\hline
\end{tabular}

${ }^{1}$ Processed without steam blanching, with water immersion and without exhausting.

" Processed without steam blanehing, blanching with water immersion and with exhausting.

${ }^{3}$ Processed with steam blanching, blanching with water immersion and without exhausting.

* Processed with steam blanching, blanching with water immersion and with exhausting. 
Tables 4 and 5 summarize the nutritional contents of the two portions of pigeon peas indicated in the flowchart after the application of the respective treatments throughout the proeess.

The results of the analyses of variance in table 4 indicate that the contents of 1) $\mathrm{P}$, 2) $\mathrm{K}$, 3) $\mathrm{Na}$, 4) $\mathrm{Ca}, 5$ ) $\mathrm{Mg}$, 6) $\mathrm{Mn}, 7$ ) $\mathrm{Fe}, 8$ ) ash, 9) total fats and 10 ) vitamin $B_{2}$ show a significant difference at the $5 \%$ probability level among the respective treatments: 1) $1-2,3,4,2-3,4$; 2) 1-2, 3, 4, $2-3,4$; 3) $1-3,4,2-3,4,2-3,4,3-4$; 4) $1-2,3,4,2-3,3-4$; 5) $1-3,2-3$, $3-4$; $1-2,3,2-3,4,3-4$; 7) $1-2,3,4$; 8) $1-2,3,4,1-2,3,4$; 8) $1-2,3,4$, $2-3,4$; 9) $1-2,3,4$ and 10) $1-2,3,4,2-3,4$.

TABLE 4.-Nutritional contents of pigeon peas from portion A processed with troatments $A, B, C$ and $D$

\begin{tabular}{lrrrr}
\hline \multirow{2}{*}{ Nutrients } & \multicolumn{4}{c}{ Treatments } \\
\cline { 2 - 5 } & \multicolumn{1}{c}{$\mathrm{A}^{\mathrm{y}}$} & \multicolumn{1}{c}{$\mathrm{B}^{2}$} & \multicolumn{1}{c}{$\mathrm{C}^{*}$} & \multicolumn{1}{c}{$\mathrm{D}^{+}$} \\
\hline Proteins \% & 19.99 & 19.44 & 19.21 & 18.87 \\
$\mathrm{P} \%$ & 0.39 & 0.35 & 0.32 & 0.31 \\
$\mathrm{~K} \%$ & 1.95 & 1.46 & 1.32 & 1.27 \\
$\mathrm{Na}$ & 0.02 & 1.04 & 1.91 & 1.83 \\
$\mathrm{Ca} \%$ & 0.11 & 0.14 & 0.15 & 0.14 \\
$\mathrm{Mg} \%$ & 0.22 & 0.21 & 0.26 & 0.22 \\
Mn p/m & 10.00 & 7.50 & 12.50 & 10.00 \\
Fep/m & 97.50 & 64.50 & 66.50 & 65.60 \\
Ash \% & 4.96 & 3.92 & 7.65 & 7.20 \\
Fats $\%$ & 1.79 & 2.29 & 2.21 & 2.32 \\
Vitamin $\mathrm{B}_{2} \mathrm{\mu g} / \mathrm{g}$ & 1.53 & 1.17 & 0.68 & 0.66 \\
\hline
\end{tabular}

Processed without steam blanehing.

${ }^{2}$ Processed with blanching in water immersion.

${ }^{3}$ Processed withont exhausting.

\& Processed with exhausting.

TABLE 5.-Nutritional contents of pigeon peas from portion B processed with treatnents $A, B, C$ and $D$

\begin{tabular}{lcccc}
\hline \multirow{2}{*}{ Contents } & \multicolumn{4}{c}{ Treatments } \\
\cline { 2 - 5 } & $\begin{array}{c}\text { Steam } \\
\text { blanehing }\end{array}$ & $\begin{array}{c}\text { Blanching with } \\
\text { water innersion }\end{array}$ & $\begin{array}{c}\text { No } \\
\text { exhausting }\end{array}$ & Exhausting \\
\hline Proteins \% & 19.68 & 19.18 & 18.75 & 18.68 \\
P\% & 0.39 & 0.35 & 0.32 & 0.33 \\
$\mathrm{~K} \%$ & 1.85 & 1.28 & 1.16 & 1.11 \\
$\mathrm{Na} \%$ & 0.03 & 0.05 & 1.92 & 1.66 \\
$\mathrm{Ca} \%$ & 0.10 & 0.12 & 0.13 & 0.12 \\
$\mathrm{Mg} \%$ & 0.21 & 0.14 & 0.29 & 0.26 \\
$\mathrm{Mn} p / \mathrm{m}$ & 6.50 & 8.00 & 10.50 & 10.00 \\
$\mathrm{Fep} / \mathrm{m}$ & 57.00 & 72.50 & 65.50 & 63.50 \\
$\mathrm{Ash} \%$ & 4.31 & 3.20 & 7.14 & 6.44 \\
$\mathrm{Fats} \%$ & 2.11 & 2.32 & 2.42 & 2.10 \\
$\mathrm{Vit} \mathrm{B} / \mathrm{g} / \mathrm{g}$ & 1.77 & 1.76 & 0.80 & 0.65 \\
\hline
\end{tabular}


The results imply that the application of treatments 2,3 and 4 contributes to the nutritional loss of $\mathrm{P}, \mathrm{K}, \mathrm{Ca}, \mathrm{Mg}, \mathrm{Mn}$ and $\mathrm{Fe}$; to the gain of $\mathrm{Na}$, and to the retention of ash and total fats.

According to the analyses of variance (table 5) it was determined that the contents of protein, $\mathrm{P}, \mathrm{K}, \mathrm{Na}, \mathrm{Ca}, \mathrm{Mg}, \mathrm{Mn}, \mathrm{Fe}$, ash, total fats and vitamin $\mathrm{B}_{2}$ show a significant difference at the $5 \%$ probability level between the respective treatments: 1) $1-3,4$; 2) $1-2,3,4,2-3$; 3) $1-2,3$, $4,2-3,4$; 4) $1-3,4,2-3,4,3-4$; 5) $1-2,3,4$; 6) $1-2,3,4,2-3,4$; 7) 1-2, 3,4 ; 8) $1-2,3,4,2-3,4,3-4$; 9) 1-2, 3, 4, 2-3, 4, 3-4; 10) 1-2, 3, 4 and 11) $1-3,4,2-3,4$.

The results imply that the application of treatments $1,2,3$, and 4 do not contribute significantly to the retention or loss of total fats, $\mathrm{P}$ and $\mathrm{Ca}$. Treatments 3 and 4 contribute to the addition of $\mathrm{Na}, \mathrm{Mg}$ and ash, and to the loss of $\mathrm{K}$ and vitamin $\mathrm{B}_{2}$.

\section{RESUMEN}

El efecto del procesamiento en el contenido nutricional de gandules (Cajanus cajan (L.)), enlatados y frescos

Se trataron dos porciones de gandules para determinar su contenido nutricional después de cada tratamiento con y sin escaldadura con vapor de agua, escaldadura por inmersión en agua caliente y expulsión con vapor de agua.

Los análisis de laboratorio y el análisis estadístico sugieren la posibilidad de la pérdida de algunos de los nutrimentos. La escaldadura con vapor de agua probablemente puede causar la pérdida de contenido en $\mathrm{K}$, Ca y $\mathrm{Mg}$. Además podría ser un factor determinante de la retención de Fe. La expulsión con vapor de agua probablemente pueda causar la pérdida de $\mathrm{K}, \mathrm{Ca}, \mathrm{Mg}$, $\mathrm{Fe}$, y la vitamina $\mathrm{B}_{2}$.

El contenido nutricional que se obłuvo de los gandules después de aplicarles los tratamientos a las porciones $A$ y $B$ indican la posibilidad de una tendencia a perderse consecutivamente $\mathrm{K}, \mathrm{Mn}$, Fe y $\mathrm{Ca}$ y a una tendencia a aumentar el contenido en vitamina $B_{2}$ en los gandules de la porción $B$.

\section{LITERATURE CITED}

1. Anonymous, 1979. The Food and Kindred Products Industry in Ptierto Rieo, Industrial Profiles Series. Commonwealth of Puerto Rico, Economic Development Administration, Office of Fconomic Research, General Economics Division, San Juan, Puerto Rico.

2. Asenjo, C. F, E. R. Hernández, L. D. de Rodríguez and M. G, de Andino, 1968. Vitamins in Canned Puerto Rican Fruit Juices and Nectars, J. Agric., Univ. P. R. 52 (1): $64-70$,

3. Augustin, J., B. G. Swanson, C. Teitzel, S. R. Johnson, S. F. Pometto, W. E. Antz, C. P. Huang and C. Sehomaker, 1979. Changes in the Nutrient Composition During Commercial Processing of Frozen Potato Products, J. Ed. Sei. 44 (3): 807-9.

4. Barrat, B., 1973. Nutrition: 2, Effect of Processing, Food in Canada 33 (2): 28-31.

5. Bluestein, P. M. and T. P. Labuzza, 1975. Effects of Moistme Removal of Nutrients, 
Ch. 11 In "Nutritional Evaluation of Food Processing", R. S. Harris and E. Karmas, Eds, AVI Publ. Co., Ine., Westport, Conn.

6. Chen, T. S. and R. C. Cooper, 1979. Thermal Destruction of Folacin: Effect of Folacin: Effect of Ascorbic Acid, Oxygen and Temperature, J. Ed. Sci. 44 (3): 713-6.

7. Commonwealth of Puerto Rico, Department of Agriculture, Office of Agricultural Statistics, Facts and Figures on Puerto Rico's Agriculture, 1981/82 1982/83: 56-7, 1983-84.

8. Economic Development Administration, Office of Economical Research, General Economies Division, The Food and Kindred Products Industry in Puerto Rico, January, 1980.

9. Feaster, J. F., 1960. Effeets of Commercial Processing on the Composition of Fruits and Vegetables. A. Washing, Trimming and Blanching, in "Nutritional Evaluation of Food Processing", R. S. Harris and H. Von Loesecke, Eds. John Wiley and Sons, Ine, N. Y.

10. Fenma, O., 1977. Loss of Vitamins in Fresh and Frozen Foods, Food Teehnol. 31 (12): 325,38 .

11. Fiske, S. H. and Y. Subbarrow, 1925. Colorimetric Determination of Phosphorous, Biol. Chem. 66 (2): 375-400.

12. Goodard, M. S. and R, H. Mathews, 1979. Current Knowledge of Nutritive Values of Vegetables, Food Technol. 33 (2): 71-3.

13. Harris, R. E. and H. Von Loesecke, 1960. Nutritional Evaluation of Food Processing, John Wiley and Sons, New York.

14. Hurt, H. D., 1979. Effect of Canning on the Nutritive Value of Vegetables, Food Technol, 33 (2): 625 .

15. Joslyn, M. A., 1966. The Freezing of Fruits and Vegetables in "Cryobiology", H. T. Meryman, Fd, Academic Press, N. Y.

16. Karel, M., 1979. Effect of Storage on Nutrients Retention of Foods, Food Technol. 33 (2): $36-7$.

17. Labuzza, T. P., 1973. Symposium: Effects of Proeessing, Storage and Handling on Nutrients Retention in Foods, 2. Effects of Dehydration and Storage, Food Technol. 27 (1): $20-1,23,25-6,51$.

18. Iee, F. A., 1958. The Blanching Process in "Advances in Food Research", E. M. Mrak and E. F. Steward, Eds, Academic Press, N. Y. 8: 63.

19. Lin, K. C., B. S. Lub and B. S. Schweigert, 1975. Folic Acid Content of Canned Garbanzo Beans, J. Ed. Sci, 40 (3): 562-5.

20. Luh, B. S., M. Karbasi and B. S. Schweigert, 1978. Thiamine, Riboflavin, Niacin and Color Retention in Canned Small White and Garbanzos Beans as Affected by Sulfite Treatment, J. Ed. Sei, 43 (2): $431-4$.

21. Methods of Vitamin Assay, 2nd ed, 1951. Interscience Publisher Ine., New York.

22. Official Methods of Analysis, 1975. Association of Official Agricultural Chemists, 12th ed, Washington, D. C.

23. Saldanã, G., T. S. Stephens, R. Meyer and B. J. Lime, 1978. Effects of Peeling Methods on the Nutritive Content of Whole Canned (Hico III). Tomatoes, J. Ed. Sei. 43 (2): 644-5.

24. Sánchez Nieva, F., A. J. Rodriguez and J. R. Benero, 1961. Improved Method of Canning Pigeon Peas, Bull. 157. Agric. Exp. Stn. Univ. P. R.

25. - M. A. Gonzalez and J. R. Benero, 1961. The Effects of Some Processing Variables on the Qualities of Canned Pigeon Peas, J. Agrie. Univ. P. R. 45 (4): 232-58. 


$$
\text { . }
$$

